\title{
The Behavioral Factors and Promoting Measures of Automobile Financial Service Industry in China
}

\author{
Mengxuan Liu', a , Hui Wang ${ }^{2, b}$ \\ ${ }^{1}$ College of Literature and Management, Hebei Agricultural University, Baoding 071001, Hebei Province, \\ China \\ ${ }^{2}$ College of Literature and Management, Hebei Agricultural University, Baoding 071001, Hebei Province, \\ China \\ a liumengxuan@126.com, ${ }^{\mathrm{b}}$ wanghui@126.com
}

Keywords: automobile financial services; behavior factors; countermeasure research purpose

\begin{abstract}
In recent years, our country's car industry is developing rapidly, becoming a major bright spot in the national economy. The development of the automotive industry, however, lacks adequate financial support, and the automobile financial service now is to optimize the structure of the auto industry, help consumer car service smoothly, further reduce automobile enterprise capital turnover time, becoming the important link in the process of development of the auto industry. However, there is a certain gap between the present development situation of financial services industry in China and rapid development of automobile industry in foreign developed countries. Especially along with China's successful entry into the WTO, our country's automobile financial service has been opening to the outside world, therefore, how to effectively cope with fierce competition in foreign automobile financial company and how to ensure the healthy development of automotive financial services industry in our country, has become the main problem discussed in this paper. This paper combs related development background and theoretical concepts of the automobile financial service, combined with the practical application of automobile development in our country to further analyze the existing problems, put forward the perfect targeted measures, and provide useful reference for the automobile financial service in the initial stage in China.
\end{abstract}

\section{Introduction}

In China, the automobile financial service industry has just started, its development time is very short, but the development momentum is swift and violent, has greatly promoted the economic development. In addition, it is the stage of the development of national automobile industrialization and financial service, and the auto financial service industry is the necessary stage to satisfy the automobile consumption market. Based on deep research on the behavioral factors and promotion measures of domestic automobile financial service industry, the author explores the present situation and shortcomings of automobile financial service development in China through the analysis of the combination of theory and practice. The paper puts forward some suggestions for the sustainable development of automobile financial services in China.

At present, automobile financial service is the most valuable link in the whole process of automobile manufacturing in the process of continuous development and expansion of automobile market in our country. Since the establishment of personal automobile consumption credit business in China, the role of automobile service industry in promoting the automobile sales market is obvious. However, since the automobile service industry in China has just started, Most of the institutions engaged in this business lack the ability to handle professional automobile financial services. In addition, because of the gaps in the domestic personal credit system, the legal imperfections and the increasing volatility of the domestic automobile market, this caused a large number of phenomena such as related fraud and malicious loan evasion, which resulted in the insurance of the public. The company forced to suspend and clean up its car loan-related insurance business after a long period of stubbornly high claims on auto insurance. This situation raises the 
risk coefficient of banks, resulting in a huge amount of loans provided by commercial banks are likely to turn into non-performing assets, and eventually banks will have to raise the conditions required for car loans.

\section{Automobile Financial Service Concept}

At present, the development of auto financial service industry has not really constituted an independent service system. The financial service industry is to integrate the development theory of economy, finance and automobile industry. In a broad sense, the automotive financial service industry should include the following key factors: auto finance related institutions, mainly for the financing of auto sales, auto financial products development, financial financing media, auto financial markets including financing sites; Provide guaranteed rules and regulations and laws and regulations for the normal operation of the auto financial system. Automobile financial service industry is a complete framework composed of many key elements.

\section{Ensure Supply Balance}

The development of automobile financial services related to the production and consumption in the process of automobile industry development. The development of automobile manufacturing industrialization needs the corresponding allocation of financial services to provide financial support. This also reflects the adjustment of the product structure of automobile financial service development, which can promote the progress and improvement of automobile industrialization, and has a strong driving effect on people actual and potential automobile consumption market demand. However, the development of automobile financial service demand in our country cannot meet its development demand, thus forming the surplus of productive forces in the market, but the buyer's market with insufficient funds from consumers. How can the social consumption fund be effectively adjusted, guide it to realize the time, the balance, the full supply, which is the basic function of the current automobile financial service development. From the point of view of its operation and circulation, the automobile finance can play an effective role in the field of automobile consumption, and promote the capital in automobile production. In the field of production, circulation and consumption, the smooth circulation of circulation in the field of circulation and consumption can maintained to achieve synchronous development, further meet the demand for funds in various fields of automobile manufacturing industry, and play an active and promoting role in the development of the automotive industry as a whole.

\section{Constraints of Financing Channels}

In the more mature financial market environment in developed countries, auto-financing companies mainly adopt the method of debt financing to meet their own needs for capital. Selling commercial paper to institutional investors in its debt structure is the main source of funding. Such regulations have resulted in a lack of diversity in the sources of funding for domestic auto financing companies and a lack of diversified alternative funding channels.

\subsection{Lack of social credit consciousness}

In China, the credit mechanism and credit management are absent to different degrees, which makes the automobile financial service of our country fall into the difficult situation of development. This development makes it difficult for financial institutions to accurately the control of credit risk by banks and other financial institutions. As a result, the automobile financial service institutions in our country set too strict and complicated procedures for providing consumer loans for automobiles, and the scope of choice for automobiles is relatively narrow. Because cars belong to the category of "movable property", they are much larger than consumer credit such as housing. The risk, our country's this aspect system is not perfect, thus increased the automobile finance to carry out the difficulty. Development and problems of Automobile Financial Service in China 


\subsection{Excessive reliance on banks for auto finance}

At present, as there is basically no real establishment of auto financing companies in our country, consumer loans for automobiles are mainly to be financed from the four major state-owned commercial banks, including some privately owned commercial banks, which are also gradually participating. It is difficult to adjust the structure of automobile finance because of its large capital flow. This is the realistic difficulty of automobile finance in our country, that is, automobile finance overdependence on banks, which leads to more restrictions on automobile consumption.

\subsection{Lack of support from local auto finance companies}

In recent years, our car has been used as a relatively good national automobile industry for China ' s domestic cars, and has been sold by car loans provided by banks, and the support of local auto finance companies is lacking. China has no car financial Services Company owned by Western automobile companies, and the automobile consumer credit business used for automobile consumption through the automobile company contacting the bank, or the customer contacts the loan business for automobile consumption.

\subsection{The supervision mechanism of automobile financial mechanism is not in place}

There are some problems in the supervision of automobile financial mechanism in our country. Because the auto financial service industry in our country is not perfect enough, we can only transfer or sell the accounts receivable from single auto loan business and teammates' car loan. As for the intermediate links in the automobile finance process, they managed through automobile finance. This related to the strengthening of supervision and management in China's financial and automobile credit business. Auto finance companies cannot issue bonds without authorization. China's auto finance companies cannot set up branches, which limits the expansion of China's auto finance credit companies largely. It is all... It is a measure to strengthen the regulation management of automobile financial service industry in our country, and it is that by strengthening supervision, we can create a fair, reasonable and standardized regulatory atmosphere and promote the steady development of automobile financial service industry. However, due to the lack of financial supervision in our country and the lack of development in many aspects of management and regulation, the smooth development of automobile financial service industry in China has been restricted.

\section{Measures to Strengthen the Development of Automobile Financial Service in China}

Train professional automobile financial service institutions. In the development of auto finance in China, we should pay attention to the training of professional automobile financial services institutions. China should introduce a series of preferential policies as soon as possible, encourage the establishment of specialized financial institutions, and do our utmost to introduce foreign banks and insurance companies. Securities companies set up regional headquarters or branches in China to provide support for the establishment of non-bank financial institutions such as auto finance companies, enterprise finance companies, financial leasing companies, etc. In addition, if the domestic financial institutions are bigger and stronger, if they are not in conflict with the national laws and regulations, the domestic government should provide encouraging and supportive laws and regulations for the development of local automobile financial institutions, to provide them for the future automobile finance. The establishment of the division laid the foundation for persistence.

China's auto financial services are in poor condition, as shown in the table below is a schematic chart of loans by financial institutions in 2014. 
Table 1

\begin{tabular}{|c|c|c|}
\hline project & Auto loan finance (willingness) & Proportion(\%) \\
\hline State-owned commercial bank & 1580 & 86 \\
\hline Joint-stock bank & 238 & 11 \\
\hline $\begin{array}{c}\text { Finance companies and motor } \\
\text { finance companies }\end{array}$ & 42 & 3 \\
\hline amount to & 1845 & 100 \\
\hline
\end{tabular}

Automobile finance as a derivative of financial industry, its development is restricting by the development of market-oriented reform of financial industry in China. At present, China has started to promote the further reform and opening up of capital market from four aspects: the reform of capital market, the reform of banking industry, the mercerization of interest rate and the construction of supervision system. The reform of China's financial management system in mercerization will create a more suitable policy environment for the smooth development of the auto finance industry. To promote the risk control of automobile financial institutions, we should focus on the two aspects of system construction and personnel management, and promote the continuous improvement of the internal control system and the customer evaluation system of automobile financial institutions. To ensure that auto financial institutions continue to improve their risk awareness and ability to prevent. Attention should pay to the continuous improvement of the internal control system of automobile financial institutions. Set up and perfect the management organization of the company, formulate the scientific and efficient management decision mechanism. Establish perfect business procedures in all departments, positions, links, etc., and check the operating efficiency and risk control of each procedure regularly. Establish an effective early warning system for internal control. This is in order to realize the early prediction of the possible problems and mistakes, to make the problems in the operation urgent to find, to prevent the gradual development of the microscopes, to minimize the mistakes and losses.

Therefore, financial institutions should set up regular business analysis, risk assessment of capital use, quality evaluation of credit assets, etc. Establish a system of periodic physical counts and reconciliation of various accounting statements, supervision system before and after business activities; improve the evaluation and feedback related to internal control systems; establish forecasting with a tendency to predict, A system of problems such as seeding. This minimizes the incidence of business risk. Cultivate and improve the risk awareness of internal staff and promote the gradual formation of a better culture of internal control. Pay attention to the continuous improvement of customer credit rating system. We should actively establish and improve the database and credit rating system related to personal credit information. Every means should found to promote the continuous improvement of the enterprise credit rating system. At the same time, it should be supplemented by external credit rating agencies to obtain more detailed customer credit information. In short, automobile finance as an important driving force of automobile industry and financial industry belongs to the new thing of our country. After China joined the WTO, China's auto finance industry has gradually increased its opening to the outside world. However, due to the strict regulation of automobile finance in China, it is difficult to play its due role in the current development of the automobile industry in China. The automobile finance of our country lacks the ability to control the risk forcefully; the entry of foreign auto finance companies into the auto finance market of China will certainly aggravate the competition of domestic automobile finance industry, which is not perfect for the automobile finance service industry. Development exerts great pressure. From this point of view, the development of China's auto financial services industry is difficult and the road is bumpy. At the same time, the domestic auto financial services industry will be confronted with active cooperation between auto finance companies, auto manufacturers, insurance, banks and other professional organizations based on their respective advantages in the initial stage. This gives our country's automobile finance service industry to provide the very good study opportunity. The continuous development of China's auto financial market will promote the rapid development of China's auto financial service industry in the process of continuous 
improvement and innovation.

\section{References}

[1] M. Gong x, who attended the 10th anniversary of the founding of the People's Republic of China. The Current Situation and Countermeasure of Tianjin Automobile Financial Services. China Business. 2014 (05)

[2] Zhang Fu sh. Problems and Solutions of Automobile Financial Fund chain [J]. Time finance. (2013 / 03)

Pan Jin, Lu Y yang. Study on the Construction of "311" training Base for Automobile Financial Service Specialty [J]. China market. (2011 / 23)

[3] Liu Z w, Liang Z t. A study on the Development of China's own Brand Automobile Financial Service [J]. Jilin agriculture. 2011 / 06)

[4] Wu Song. Research on Optimization of Auto Dealer financing Business Model of Jilin Branch of J tong Bank [D]. Jilin University 2014

[5] Q Yan. Research on improvement of Marketing Strategy of FAW Automotive Finance Co., Ltd. [D]. Ma J, Zhengzhou University 2013 [16]. Research on supply chain Financial Service of Automobile Industry in China [D]. Ocean University of China 2013

[7] Liu B f. Research on Development Strategy of Volkswagen Finance Company based on Industrial value chain [D]. H b University of Technology 2013

[8] Cao Gang. Research on the financing Mode under the Tripartite Agreement among Banks, Automobile Manufacturers and Dealers [D]. Jilin University 2012 